\title{
Effect of Foliar Application of Siliceous Nanomaterial on Photosynthesis Performance in Sweet Almond (Prunus dulci) ${ }^{\dagger}$
}

\author{
Marius Ghiurea ${ }^{1}$, Cristina Moale ${ }^{2}$ and Florin Oancea ${ }^{1, *}$ \\ 1 National Institute for Research \& Development in Chemistry and Petrochemistry - ICECHIM, \\ 202 Spl. Independentei, 060021 Bucharest, Romania; ghiurea@gmail.com \\ 2 Agricultural Research and Development Station, 460 Calea Dobrogei, 907300 Valul-lui-Traian, \\ Jud. Constanța, Romania; moalecristina@yahoo.com \\ * Correspondence: florin.oancea@icechim.ro \\ + Presented at the 16th International Symposium "Priorities of Chemistry for a Sustainable Development" \\ PRIOCHEM, Bucharest, Romania, 28-30 October 2020.
}

Published: 13 November 2020

Keywords: foliar application; natural siliceous nanomaterial; diatomaceous earth; natural zeolites; clinoptilite; foliar fertilizer

Siliceous natural nanomaterials, i.e., diatomaceous earth and natural zeolites, are biorational products, generally recognized as safe (GRAS) due to their large utilization as dietary supplement [1] and food/feed additive [2]. Applied as foliar treatment, such siliceous natural nanomaterials (SNNMs), have plant biostimulant effects, due to a combination of protection against UV radiation, an anti-transpirant effect and stimulation of photosynthesis [3]. Stimulation of photosynthesis results mainly from the local concentration effect of the siliceous natural nanomaterials on the $\mathrm{CO}_{2}[4]$. Combinations of NPK foliar fertilizer and diatomaceous earth, and, respectively, zeolites, were tested for their influence on sweet almond (Prunus dulci) photosynthesis. Such combinations intend also to generate a slow release formulation of the NPK fertilizer, exploiting the excellent characteristics of the used siliceous nanomaterials as ion exchangers.

Diatomaceous earth (Adamclisi, Constanza, Romania, marine origin, average dimension $8 \mu \mathrm{m}$ ) and natural zeolites - clinoptilite type (Rupea, Brasov, Romania) were used in this study. An NPK with microelement formulation was included into siliceous natural nanomaterials. The ratio between foliar fertilizer and siliceous natural nanomaterial was of 2 to 1 . The foliar fertilizer was a NPK 3.5:15:2 with the following microelement: $20 \mathrm{mg} / \mathrm{kg} \mathrm{Cu}, 25 \mathrm{mg} / \mathrm{kg} \mathrm{Zn,} 17 \mathrm{mg} / \mathrm{kg} \mathrm{Fe}, 8 \mathrm{mg} / \mathrm{kg} \mathrm{Mn}, 3 \mathrm{mg} / \mathrm{kg} \mathrm{B}$. Selenium (as biogenic nanoparticles) was included also in the complex formulation, as $2 \mathrm{mg} / \mathrm{kg}$. The adhesion to leaves of the siliceous nanomaterial was enhanced by incorporation of $5 \%$ chitosan. The foliar fertilizer complexed with SNNMs was applied in the beginning of June 2018, in a dose equivalent to $7.5 \mathrm{~kg}$ per ha. The product was applied to sweet almond (Prunus dulci), cv. Preanîi, from an orchard located in Valul-lui-Traian (Constanza, Romania), Lat. 44 ${ }^{\circ}, 10^{\prime} 38.05^{\prime \prime} \mathrm{N}$, Long. $28^{\circ} \mathrm{C}, 29^{\prime}$, $4.54^{\prime \prime}$, on a soil with significant selenium deficit. Determination of photosynthesis parameters were done by using a portable system LCproT Advance (ADC Bioscientific, Herts, UK), a portable fluorimeter (PAM, Waltz, Effeltrich, Germany) and a porometer (AP4, Delta-T Devices, Cambridge, UK).

The analysis of the experimental data demonstrate that the application of the SNNMs complexed with foliar fertilizer, in dose equivalent to $7.5 \mathrm{~kg} / \mathrm{ha}$, enhanced the photosynthesis process in sweet almond, due to a combined effect, optimization of the leaf temperature and increase of the substomatal $\mathrm{CO}_{2}$ concentration. Application of siliceous natural nanomaterial enhance the photosynthesis in sweet almond leaves. 
Acknowledgments: The work on this paper was supported by the Romanian Ministry of Agriculture and Rural Development, project "Research on the biological activity of some nanomaterial-based products on major pest and pathogens of fruit trees and assessment of the ecotoxicological impact of these on useful entomofaunaADER 7.3.9".

\section{References}

1. Mumpton, F.A. La roca magica: Uses of natural zeolites in agriculture and industry. Proc. Natl. Acad. Sci. USA 1999, 96, 3463-3470. doi:10.1073/pnas.96.7.3463.

2. Anastassiadou, M.; Arena, M.; Auteri, D.; Brancato, A.; Bura, L.; Carrasco Cabrera, L.; Chaideftou, E.; Chiusolo, A.; Marques, D.C. Peer review of the pesticide risk assessment of the active substance kieselgur (diatomaceous earth). EFSA J. 2020, 18, e06054.

3. De Smedt, C.; Someus, E.; Spanoghe, P. Potential and actual uses of zeolites in crop protection. Pest Manag. Sci. 2015, 71, 1355-1367. doi:10.1002/ps.3999.

4. De Smedt, C.; Steppe, K.; Spanoghe, P. Beneficial effects of zeolites on plant photosynthesis. Adv. Mater. Sci. 2017, 2, 1-11.

Publisher's Note: MDPI stays neutral with regard to jurisdictional claims in published maps and institutional affiliations.

(C) 2020 by the authors. Licensee MDPI, Basel, Switzerland. This article is an open access article distributed under the terms and conditions of the Creative Commons Attribution (CC BY) license (http://creativecommons.org/licenses/by/4.0/). 